\title{
Critical Reappraisal of Methods for Measuring Urine Saturation with Calcium Salts
}

\author{
Silvia Berto ${ }^{1, *(\mathbb{C}}$, Martino Marangella $\left.{ }^{2} \mathbb{(}\right)$, Concetta De Stefano ${ }^{3}$, Demetrio Milea ${ }^{3}(\mathbb{1})$ and Pier Giuseppe Daniele ${ }^{1,+}$ \\ 1 Dipartimento di Chimica, Università di Torino, via P. Giuria 7, 10125 Torino, Italy; pierodan2015@gmail.com \\ 2 Fondazione Scientifica Mauriziana-Onlus, via Magellano 1, 10128 Torino, Italy; mmarangella@alice.it \\ 3 Dipartimento di Scienze Chimiche, Biologiche, Farmaceutiche ed Ambientali, Università degli Studi di \\ Messina, CHIBIOFARAM, Viale Ferdinando Stagno d'Alcontres 31, 98166 Messina, Italy; \\ cdestefano@unime.it (C.D.S.); dmilea@unime.it (D.M.) \\ * Correspondence: silvia.berto@unito.it \\ + This work is lovingly dedicated to a friend and colleague, Prof. Silvio Sammartano, who has always worked \\ on the equilibria thermodynamics with intelligence, scientific integrity and judgment. He worked with us on \\ this topic for many years, but sadly, he passed away before the publication of this work.
}

Citation: Berto, S.; Marangella, M.; De Stefano, C.; Milea, D.; Daniele, P.G. Critical Reappraisal of Methods for Measuring Urine Saturation with Calcium Salts. Molecules 2021, 26, 3149. https://doi.org/10.3390/ molecules26113149

Academic Editor: Cristobal De Los Rios

Received: 6 May 2021

Accepted: 22 May 2021

Published: 25 May 2021

Publisher's Note: MDPI stays neutral with regard to jurisdictional claims in published maps and institutional affiliations.

Copyright: (C) 2021 by the authors Licensee MDPI, Basel, Switzerland. This article is an open access article distributed under the terms and conditions of the Creative Commons Attribution (CC BY) license (https:/ / creativecommons.org/licenses/by/ $4.0 /)$.
Abstract: Background: Metabolic and physicochemical evaluation is recommended to manage the condition of patients with nephrolithiasis. The estimation of the saturation state ( $\beta$ values) is often included in the diagnostic work-up, and it is preferably performed through calculations. The free concentrations of constituent ions are estimated by considering the main ionic soluble complexes. It is contended that this approach is liable to an overestimation of $\beta$ values because some complexes may be overlooked. A recent report found that $\beta$ values could be significantly lowered upon the addition of new and so far neglected complexes, $\left[\mathrm{Ca}\left(\mathrm{PO}_{4}\right) \mathrm{Cit}\right]^{4-}$ and $\left[\mathrm{Ca}_{2} \mathrm{H}_{2}\left(\mathrm{PO}_{4}\right)_{2}\right]$. The aim of this work was to assess whether these complexes can be relevant to explaining the chemistry of urine. Methods: The Ca-phosphate-citrate aqueous system was investigated by potentiometric titrations. The stability constants of the parent binary complexes $[\mathrm{Cacit}]^{-}$and $\left[\mathrm{CaPO}_{4}\right]^{-}$, and the coordination tendency of $\mathrm{PO}_{4}{ }^{3-}$ toward $[\mathrm{Ca}(\mathrm{cit})]^{-}$to form the ternary complex, were estimated. $\beta_{\mathrm{CaOx}}$ and $\beta_{\mathrm{CaHPO} 4}$ were then calculated on 5 natural urines by chemical models, including or not including the $\left[\mathrm{CaPO}_{4}\right]^{-}$and $\left[\mathrm{Ca}\left(\mathrm{PO}_{4}\right) \mathrm{cit}\right]^{4-}$ species. Results: Species distribution diagrams show that the $\left[\mathrm{Ca}\left(\mathrm{PO}_{4}\right) \mathrm{cit}\right]^{4-}$ species was only noticeable at $\mathrm{pH}>8.5$ and below $10 \%$ of the total calcium. $\beta$ values estimated on natural urine were slightly lowered by the formation of $\left[\mathrm{CaPO}_{4}\right]^{-}$species, whereas $\left[\mathrm{Ca}\left(\mathrm{PO}_{4}\right) \text { cit }\right]^{4-}$ results were irrelevant. Conclusions: While $\left[\mathrm{CaPO}_{4}\right]^{-}$species have an impact on saturation levels at higher $\mathrm{pHs}$, the existence of ternary complex and of the dimer is rejected.

Keywords: nephrolithiasis; calcium oxalate; calcium phosphate; citrate; chemical speciation; oversaturation

\section{Introduction}

Nephrolithiasis (NL) is a common disease that is characterized by high rates of recurrence [1]. Medical management is aimed at preventing stone reappearance. It is generally agreed that the metabolic and physicochemical evaluation of urine may help to guide physicians to choose adequate therapies and to control for patients' compliance [2]. Concerning calcium NL, the risk of forming stones stems from an imbalance between urine components promoting (e.g., calcium, oxalate, and phosphate) and inhibiting (e.g., magnesium, citrate, and macromolecules) NL [3]. The interactions among these moieties regulate crystallization through thermodynamic and/or kinetic processes. Whereas techniques for measuring crystal kinetics are mainly performed for research purposes only, being time-consuming and poorly standardized, the thermodynamic approach, based on the assessment of the urine saturation state, is often included in the metabolic evaluation of patients. There are essentially two methods to perform such measurements: the semi-empirical one proposed by Pak et al. [4], and the computer-based calculations 
formerly proposed by Robertson et al. [5]. While Pak's method has been seldom used due to its complexity, several computer-based calculations, including EQUIL [6], JESS [7], and Lithorisk ${ }^{\circledR}$ [8], have been proposed and recommended in the management of patients with NL [9].

While such calculations represent a valuable approach to estimating the tendency to form stones, some problems remain concerning the comparability between methods. In principle, calculations are based on the estimation of the free ion concentration product of the constituent ions of calcium salts. This can be provided if the most important soluble complexes of calcium, oxalate and phosphate are introduced into the calculation [10]. The complexes formed depend on the components of urine, and the concentration of the complexes depends on their stability constant. The components of the speciation models were selected based on the Geigy tables [11]. Different results between methods may arise from differences in the number and type of stability constants used. The JESS (joint expert speciation system) was recently developed, based on the availability of an extensive database of thermodynamic constants [12]. When compared to the previous EQUIL [10] method, it was shown to yield significantly lower estimations of relative supersaturation with both calcium oxalate (calcium oxalate monohydrate, COM) and calcium phosphate (brushite, BSH). This was accounted for by JESS considering two so far neglected complex species, namely, $\left[\mathrm{Ca}\left(\mathrm{PO}_{4}\right) \mathrm{Cit}\right]^{4-}$ and $\left[\mathrm{Ca}_{2} \mathrm{H}_{2}\left(\mathrm{PO}_{4}\right)_{2}\right]$. In a former paper we reported a fair correspondence between our Lithorisk ${ }^{\circledR}$ method [8] and EQUIL [10]. Therefore, similar differences are expected to emerge by comparing JESS to Lithorisk ${ }^{\circledR}$. In this paper, we aim to evaluate whether the aforementioned complexes can form in common urinary conditions and be consequently relevant in measurements of urine saturation. In order to evaluate whether these complexes form in urine on the basis of thermodynamics, the Caphosphate-citrate aqueous system was studied by $\mathrm{pH}$ - and $\mathrm{pCa}-\mathrm{metric}$ titrations, at an ionic strength of $I=0.1 \mathrm{~mol} \mathrm{~L}^{-1}$ (using $\mathrm{KCl}$ as the ionic medium) and $t=37^{\circ} \mathrm{C}$. Since an accurate evaluation of the formation constant of a ternary mixed complex requires the knowledge of the stability constants of the parent binary complexes [Cacit] ${ }^{-}$[13] and $\left[\mathrm{CaPO}_{4}\right]^{-}$, we concurrently studied the $\mathrm{Ca}$ phosphate system in the same experimental conditions. The $\mathrm{pH}$ range considered for both of the above systems was 5.0-7.5, where the dissociation of the last proton of phosphate anion can occur.

\section{Results and Discussion}

\subsection{Stability of Calcium Mixed Complexes}

Alkalimetric titrations were conducted on the Ca-phosphate and Ca-phosphatecitrate aqueous systems until the abrupt variation of potentials occurred, revealing the beginning of the precipitation of calcium-phosphate salts. An example of titration curves obtained on the Ca-phosphate-citrate system, recorded by both $\mathrm{ISE}-\mathrm{H}^{+}$and ISE-Ca ${ }^{2+}$ (ion-selective electrode (ISE)), is shown in Figure 1.

The $\mathrm{pH}$-metric data collected on the $\mathrm{Ca}$-phosphate aqueous system were used to determine the formation constant of the $\left[\mathrm{CaPO}_{4}\right]^{-}$species. Concerning the dimeric $\left[\mathrm{Ca}_{2} \mathrm{H}_{2}\left(\mathrm{PO}_{4}\right)_{2}\right]$ species, we had already reported no evidence of it when determining the stability constant of the monomeric $\left[\mathrm{CaHPO}_{4}\right]$ species [14], and this was confirmed by results obtained in our experimental conditions. In fact, the experimental data cannot be explained by chemical models containing the dimeric species. The inclusion of this species in models has always led to a marked discrepancy between the experimental curves and those calculated through the application of the model.

The optimized value of $\left[\mathrm{CaPO}_{4}\right]^{-}$species is $\log K=6.15 \pm 0.02$ (Table 1 ), which agrees with the results reported by Nancollas et al. [15]: $\log K=6.13$. The pCa values obtained by the ISE- $\mathrm{Ca}^{2+}$ measurements agree with those calculated by the chemical model (for further details on data analysis, see: Section 4.4).

By taking into account the formation constants of both parent binary complexes $[\mathrm{Cacit}]^{-}$and $\left[\mathrm{CaPO}_{4}\right]^{-}$, $\mathrm{pH}$-metric data collected by titrating ternary mixtures containing $\mathrm{Ca}(\mathrm{II})$, citrate and phosphate, were analyzed with the aim of evidencing the formation of 
ternary species. Of course, only the potentiometric data registered before the precipitation of calcium phosphates were considered. The value of the formation constant calculated for the $\left[\mathrm{Ca}\left(\mathrm{PO}_{4}\right) \mathrm{cit}\right]^{4-}$ complex is $\log \beta=8.3 \pm 0.8$. The relatively high uncertainty estimated is due to a negligible formation percentage (Table 1 ).

In order to characterize the coordination tendency of the ligand $\mathrm{PO}_{4}{ }^{3-}$ toward [Ca(cit) $]^{-}$, the value of $\Delta \log K_{\mathrm{Ca}}$ was calculated, as suggested by H. Sigel [16]. $\Delta \log K_{\mathrm{Ca}}$ is the difference between the partial formation constant of the mixed complex- $\log K_{\mathrm{CacitPO}_{4}}^{\mathrm{Cacit}}$ and the partial formation constant of the complementary complex- $\log \mathrm{K}_{\mathrm{CaPO}_{4}}$ :

$$
\begin{gathered}
\log K_{\mathrm{CacitPO}_{4}}^{\mathrm{Cacit}}=\log \beta_{\mathrm{CacitPO}_{4}}-\log K_{\mathrm{Cacit}} \\
\Delta \log K_{\mathrm{Ca}}=\log K_{\mathrm{CacitPO}_{4}}^{\mathrm{Cacit}}-\log K_{\mathrm{CaPO}_{4}}
\end{gathered}
$$

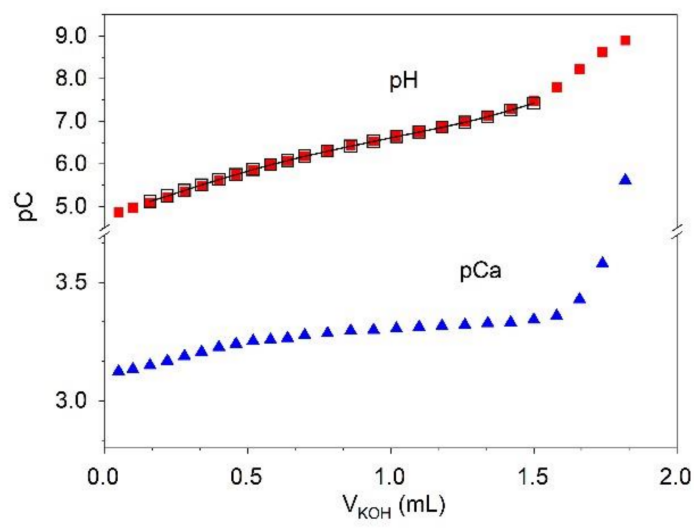

Figure 1. Titration curves recorded by both $\mathrm{ISE}_{\mathrm{H}} \mathrm{H}^{+}$and $\mathrm{ISE}^{-\mathrm{Ca}^{2+}}$ on a solution of $\mathrm{Ca}^{2+}: 0.98 \times 10^{-3} \mathrm{~mol} \mathrm{~L}^{-1} ; \mathrm{K}^{+}: 1.00 \times 10^{-1} \mathrm{~mol} \mathrm{~L}^{-1} ; \mathrm{Cl}^{-}: 1.00 \times 10^{-1} \mathrm{~mol} \mathrm{~L}^{-1} ; \mathrm{PO}_{4}{ }^{3-}: 2.35 \times$ $10^{-3} \mathrm{~mol} \mathrm{~L}{ }^{-1}$; citrate: $1.00 \times 10^{-3} \mathrm{~mol} \mathrm{~L}^{-1}$; titrant: $\mathrm{KOH} 0.1 \mathrm{~mol} \mathrm{~L}^{-1}\left(I=0.1 \mathrm{~mol} \mathrm{~L}^{-1} ; t=37^{\circ} \mathrm{C}\right)$. Full symbols: experimental points; empty black symbols-line: calculated values based on the speciation model reported in Table 1.

Table 1. Overall $(\log \beta)$ and partial $(\log K)$ formation constants at 25 and $37^{\circ} \mathrm{C}$, and at different ionic strengths, of the species

\begin{tabular}{|c|c|c|c|c|c|c|c|}
\hline \multirow{3}{*}{ Species } & \multicolumn{7}{|c|}{ Formation Constants } \\
\hline & \multicolumn{2}{|c|}{$I=0.16 \mathrm{~mol} \mathrm{~L}^{-1}, 25^{\circ} \mathrm{C}$} & \multicolumn{2}{|c|}{$I=0.16 \mathrm{~mol} \mathrm{~L}^{-1}, 37^{\circ} \mathrm{C}$} & \multicolumn{2}{|c|}{$I=0.1 \mathrm{~mol} \mathrm{~L}^{-1}, 37^{\circ} \mathrm{C}^{\mathrm{a}}[17]$} & \multirow[t]{2}{*}{ Reference } \\
\hline & $\log K$ & $\log \beta$ & $\log K$ & $\log \beta$ & $\log K$ & $\log \beta$ & \\
\hline $\mathrm{HPO}_{4}{ }^{2-}$ & 11.79 & 11.79 & $11.64^{b}$ & 11.64 & 11.68 & 11.68 & [18] \\
\hline $\mathrm{H}_{2} \mathrm{PO}_{4}^{-}$ & 6.84 & 18.63 & $6.83^{b}$ & 18.47 & 6.85 & 18.53 & [18] \\
\hline $\mathrm{H}_{3} \mathrm{PO}_{4}$ & 1.98 & 20.61 & $2.03^{b}$ & 20.51 & 2.04 & 20.57 & [18] \\
\hline $\mathrm{Hcit}^{2-\mathrm{c}}$ & & & 5.80 & 5.80 & 5.83 & 5.83 & [19] \\
\hline $\mathrm{H}_{2} \mathrm{Cit}^{-}$ & & & 4.31 & 10.11 & 4.33 & 10.16 & [19] \\
\hline $\mathrm{H}_{3}$ cit & & & 2.86 & 12.97 & 2.87 & 13.03 & [19] \\
\hline$\left[\mathrm{KHPO}_{4}\right]^{-}$ & 0.50 & 12.29 & 0.58 & 12.22 & 0.62 & 12.30 & [18] \\
\hline$\left[\mathrm{KPO}_{4}\right]^{2-}$ & 0.81 & 0.81 & 0.85 & 0.85 & 0.88 & 0.88 & [18] \\
\hline$[\text { Kcit }]^{2-}$ & & & 0.56 & 0.56 & 0.59 & 0.59 & [19] \\
\hline [CaHcit] & & & 2.03 & 7.83 & 2.05 & 7.88 & [13] \\
\hline \multirow[t]{2}{*}{ [Cacit $^{-}$} & & & 3.49 & 3.49 & 3.56 & 3.56 & [13] \\
\hline & & & \multicolumn{2}{|c|}{$I=0 \mathrm{~mol} \mathrm{~L}^{-1}, 37^{\circ} \mathrm{C}$} & \multicolumn{2}{|c|}{$I=0.1 \mathrm{~mol} \mathrm{~L}^{-1}, 37^{\circ} \mathrm{C}^{\mathrm{b}}$} & \\
\hline$[\mathrm{CaCl}]^{+}$ & & & -0.01 & -0.01 & 0.02 & 0.02 & [20] \\
\hline$\left[\mathrm{CaH}_{2} \mathrm{PO}_{4}\right]^{+}$ & & & & & 1.11 & 19.64 & [14] \\
\hline$\left[\mathrm{CaHPO}_{4}\right]$ & & & & & 2.02 & 13.70 & [14] \\
\hline$\left[\mathrm{CaPO}_{4}\right]^{-}$ & & & & & $6.15 \pm 0.02$ & $6.15 \pm 0.02$ & This work \\
\hline$\left[\mathrm{Ca}\left(\mathrm{PO}_{4}\right) \mathrm{cit}\right]^{4-\mathrm{d}}$ & & & & & $8.3 \pm 0.8$ & $8.3 \pm 0.8$ & This work \\
\hline
\end{tabular}
in the water solutions containing $\mathrm{Ca}$-phosphate and $\mathrm{Ca}$-phosphate-citrate.

${ }^{\text {a }}$ Values extrapolated from those at $I=0.16 \mathrm{M}$ upon application of the Expanded Debye-Hückel equation [17]. ${ }^{\mathrm{b}}$ Values extrapolated from the data collected at different temperatures in [17]. ${ }^{c}$ cit $=$ citrate anion. ${ }^{\mathrm{d}}$ negligible species. 
Since the $\log K$ for $\left[\mathrm{CaPO}_{4}\right]^{-}$is 6.15 , the $\Delta \log K_{\mathrm{Ca}}$ is -1.48 . The $\Delta \log K_{\mathrm{Ca}}$ quantifies the stability of the ternary complex, relative to the binary parent complex. The statistically expected value of $\Delta \log K_{\mathrm{Ca}}$, evaluated by $\mathrm{H}$. Sigel [16] for the coordination of two different bidentate ligands to a regular octahedral coordination sphere, is -0.38 . The value of $\Delta \log K_{\mathrm{Ca}}$ obtained for $\left[\mathrm{Ca}\left(\mathrm{PO}_{4}\right) \mathrm{cit}\right]^{4-}$ is more strongly negative than that statistically expected. This outcome suggests that the formation of the ternary complex is quite improbable, and this is probably due to a charge repulsion factor. The negative charges of both the parent complexes and the second ligand hinder the formation of the mixed complex.

The possibility to explain the titration data by only considering the $\left[\mathrm{CaPO}_{4}\right]^{-}$species on the one hand, and the high uncertainty of $\left[\mathrm{Ca}\left(\mathrm{PO}_{4}\right) \mathrm{cit}\right]^{4-}$ formation constants on the other, reinforce the hypothesis that the formation of the mixed species is quite unlikely.

Figure 1 shows the simulated titration curves derived from the application of the speciation model reported in Table 1, and Figure 2 illustrates the speciation diagrams for the solution under study. The figures show that the percentage of $\mathrm{Ca}^{2+}$ involved in the $\left[\mathrm{Ca}\left(\mathrm{PO}_{4}\right) \mathrm{cit}\right]^{4-}$ species is negligible. Only at a $\mathrm{pH}$ higher than 8.5 , which is uncommon in urine, the formation percentage of $\left[\mathrm{Ca}\left(\mathrm{PO}_{4}\right) \mathrm{cit}\right]^{4-}$ becomes noticeable, though it is always below $10 \%$ of total calcium. On the other hand, with $\mathrm{pH}$ as high as this, the struvite $\left(\left(\mathrm{NH}_{4}\right) \mathrm{MgPO}_{4} \times 6\left(\mathrm{H}_{2} \mathrm{O}\right)\right)$ stone formation becomes by far the most clinically relevant.
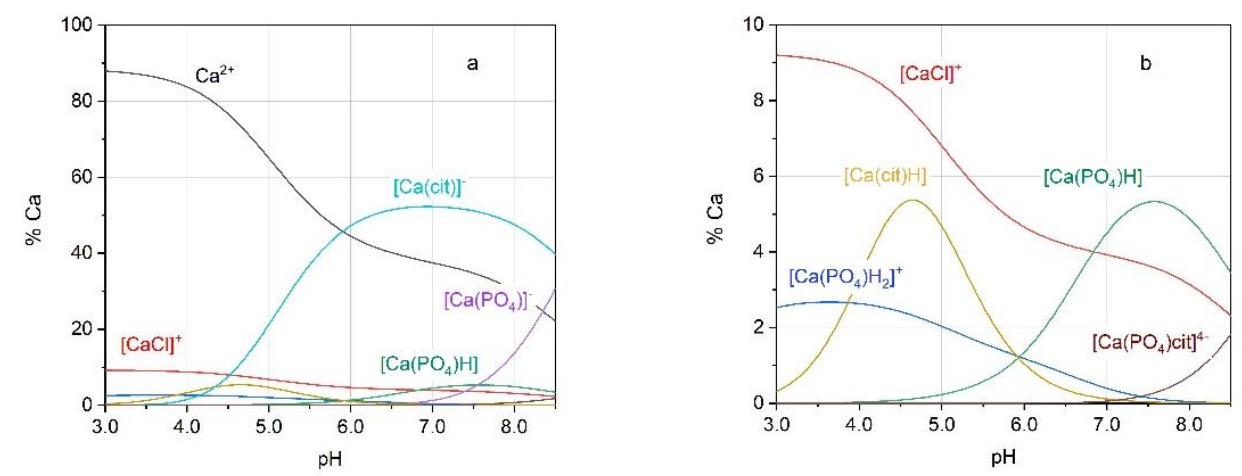

Figure 2. Speciation plots computed using the speciation model reported in Table 1. (a) Full figure; (b) zoomed figure showing the species at low formation percentage. The concentrations of the components are: $\mathrm{Ca}^{2+}: 1.0 \times 10^{-3} \mathrm{~mol} \mathrm{~L}{ }^{-1} ; \mathrm{K}^{+}: 1.0 \times 10^{-1} \mathrm{~mol} \mathrm{~L}^{-1} ; \mathrm{Cl}^{-}: 1.0 \times 10^{-1} \mathrm{~mol} \mathrm{~L}^{-1}$; $\mathrm{PO}_{4}{ }^{3-}: 2.5 \times 10^{-3} \mathrm{~mol} \mathrm{~L}^{-1}$; citrate (cit): $1.0 \times 10^{-3} \mathrm{~mol} \mathrm{~L}^{-1}\left(I=0.1 \mathrm{~mol} \mathrm{~L}^{-1} ; t=37^{\circ} \mathrm{C}\right)$.

\subsection{Calcium Complexes in Urinary Conditions}

The relevance of the species here defined, $\left[\mathrm{CaPO}_{4}\right]^{-}$and $\left[\mathrm{Ca}\left(\mathrm{PO}_{4}\right) \mathrm{cit}\right]^{4-}$, on the saturation conditions of real urine samples (the $\mathrm{pH}$ and the molar concentrations of the urine components are reported in Table S1 of the Supporting Material file) was tested. A chemical model that involves the species reported in Table S2 of the Supporting Material file (hereinafter Model 2) was applied to 5 natural urine samples with a $\mathrm{pH}$ between 6.5 and 7.5. The results were compared with those obtained by applying the previous model (hereinafter Model 1), which ignores the $\left[\mathrm{CaPO}_{4}\right]^{-}$and $\left[\mathrm{Ca}\left(\mathrm{PO}_{4}\right) \mathrm{cit}\right]^{4-}$ species. The formation constants of the herein considered species are the same as those previously used in speciation studies of some biological fluids [21,22]. On each sample, the species distribution and the saturation level with the two models were defined. The saturation level was represented by the values of $\beta_{\mathrm{CaOx}}$ and $\beta_{\mathrm{CaHPO} 4}$ calculated as previously described [23] and summarized in the Supporting Material file.

The results of the saturation levels for each urine sample, obtained by applying the two chemical models, are reported in Table 2. Figure 3 shows the species distribution diagrams of one sample of urine (the other distribution plots were collected in Figures S1 and S2 of the Supporting Material file). The species distribution diagrams were plotted in the $\mathrm{pH}$ range of 4.0-8.5, even if a $\mathrm{pH}$ higher than 7.5 is very unusual for natural urines, unless infected with urease-producing bacteria. Such a wide $\mathrm{pH}$ range was used to stress 
the formation of the $\left[\mathrm{CaPO}_{4}\right]^{-}$and $\left[\mathrm{Ca}\left(\mathrm{PO}_{4}\right) \mathrm{cit}\right]^{4-}$ species. The speciation diagrams show that, while the $\left[\mathrm{CaPO}_{4}\right]^{-}$species starts to be relevant at $\mathrm{pH}>7$, the mixed $\left[\mathrm{Ca}\left(\mathrm{PO}_{4}\right) \mathrm{cit}\right]^{4-}$ species appears to be completely negligible in this urine sample. Therefore, the changes in $\beta_{\mathrm{CaOx}}$ and $\beta_{\mathrm{CaHPO} 4}$ values obtained through Model 2, compared to Model 1, are only due to the addition of $\left[\mathrm{CaPO}_{4}\right]^{-}$species in the former.

In order to verify how an increase in citrate concentration affects the species distribution and the saturation values, the speciation diagram of urine $B$, modified by increasing total citrate concentration to $4.0 \times 10^{-3} \mathrm{~mol} \mathrm{~L}^{-1}$, was drawn as shown in Figure 3e. This test was performed on urine $\mathrm{B}$ because this is a sample with particularly high $\mathrm{pH}$ and $\mathrm{Ca}^{2+}$ concentration, which could enhance the $\left[\mathrm{Ca}\left(\mathrm{PO}_{4}\right) \mathrm{cit}^{4-}{ }^{4-}\right.$ formation (see Table S1). Under these conditions, $[\mathrm{Ca}(\mathrm{cit})]^{-}$becomes the main species in the $\mathrm{pH}$ range $5-8$, thereby reducing the percentage of free calcium and $[\mathrm{Ca}(\mathrm{ox})]$. Estimating the saturation values of urine $\mathrm{B}$, it is possible to note a strong decrease of $\beta$ values upon increasing the citrate concentration: going from a citrate concentration of $8.5 \times 10^{-4} \mathrm{~mol} \mathrm{~L}^{-1}$ to $4.0 \times 10^{-3} \mathrm{~mol} \mathrm{~L}^{-1}$, the $\mathrm{pH}$ shifts from 7.24 to 7.27 , and the $\beta_{\mathrm{CaOx}}$ and $\beta_{\mathrm{CaHPO} 4}$ change from 5.74 and 4.73 to 3.69 and 2.93, respectively (Table 2). The decrease in saturation values cannot be explained by the presence of mixed species. $\left[\mathrm{Ca}\left(\mathrm{PO}_{4}\right) \mathrm{cit}\right]^{4-}$ remains absent up to $\mathrm{pH} 7$ and reaches a percentage of only $13 \%$ at $\mathrm{pH} 8.5$.
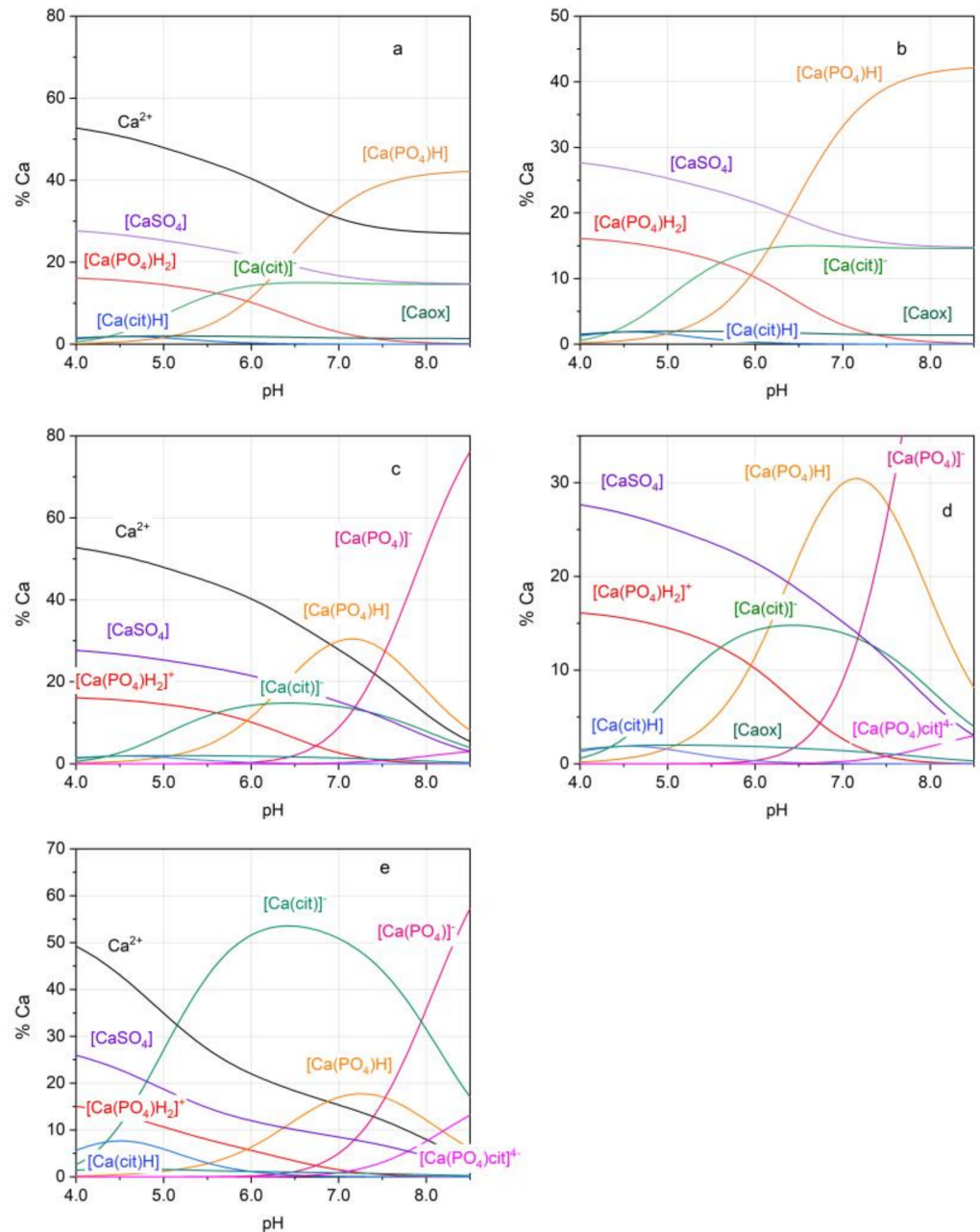

Figure 3. Speciation plots for the urine B obtained with Model 1: (a) full figure; (b) zoomed figure; and with Model 2: (c) full figure; (d) zoomed figure. (e) Speciation plots for urine B, obtained with Model 2 upon increasing total concentration of citrate to $4.0 \times 10^{-3} \mathrm{~mol} \mathrm{~L}^{-1}$; cit = citrate anion; ox $=$ oxalate anion. 
Table 2. Ionic strength $\left(I_{\text {calc }}\right)$ and saturation levels, estimated on five real urines. Model 1 does not consider the species $\left[\mathrm{CaPO}_{4}\right]^{-}$and $\left[\mathrm{Ca}\left(\mathrm{PO}_{4}\right) \mathrm{cit}\right]^{4-}$. Model 2 considers the species $\left[\mathrm{CaPO}_{4}\right]^{-}$and $\left[\mathrm{Ca}\left(\mathrm{PO}_{4}\right) \mathrm{cit}\right]^{4-}$.

\begin{tabular}{ccccccccc}
\hline Urine & $\mathbf{p H}^{\mathbf{1}}$ & \multicolumn{2}{c}{$\boldsymbol{I}_{\text {calc }}$} & \multicolumn{2}{c}{$\beta_{\text {Caox }}{ }^{2}$} & \multicolumn{2}{c}{$\beta_{\text {CaHPO }_{4}}$} \\
& & Model & $\mathbf{1}$ & $\mathbf{2}$ & $\mathbf{1}$ & $\mathbf{2}$ & $\mathbf{1}$ & $\mathbf{2}$ \\
\hline A & 7.50 & & 0.107 & 0.107 & 2.57 & 2.25 & 1.34 & 1.15 \\
B & 7.24 & & 0.148 & 0.148 & 6.76 & 5.74 & 5.71 & 4.73 \\
C & 7.06 & 0.064 & 0.064 & 2.52 & 2.33 & 3.42 & 3.10 \\
D & 6.84 & 0.148 & 0.146 & 4.67 & 4.52 & 2.37 & 2.27 \\
E & 6.57 & 0.103 & 0.103 & 9.60 & 9.49 & 2.93 & 2.87 \\
$\mathbf{B}^{* 3}$ & 7.27 & - & 0.155 & - & 3.69 & - & 2.93 \\
\hline
\end{tabular}

${ }^{1}$ experimental value measured on the samples; ${ }^{2} \mathrm{ox}=$ oxalate anion; ${ }^{3} \mathrm{~B}^{*}=$ sample $\mathrm{B}$ with increased total citrate concentration up to $4.0 \times 10^{-3} \mathrm{~mol} \mathrm{~L}^{-1}$.

\section{Discussion}

The chemical model previously proposed for measuring urine saturation was now reappraised. The method is based on the assessment of the saturation level through the estimation of free concentrations of calcium, oxalate, and hydrogen phosphate. The free concentrations were estimated by the application of a chemical model that comprises all chemical equilibria that can affect the formation of calcium oxalate and calcium phosphate species. An analogous approach was used for speciation studies of different biological fluids, providing reliable results [21], and this may be applied to other biological fields.

Previous reports [12] suggested that a citrate-related increase in urine $\mathrm{pH}$ might result in an additional decrease in saturation levels, due to an augmented formation of the $\left[\mathrm{Cacit} \mathrm{PO}_{4}\right]^{4-}$ complex. The results reported in this work suggest, instead, that the strong decrease in urine saturation with calcium salts obtained upon citrate addition was mainly due to $[\mathrm{Ca}(\mathrm{cit})]^{-}$and not to $\left.[\mathrm{CacitPO}]_{4}\right]^{4-}$. In other words, the favorable effect of citrate supplementation to calcium stone-forming patients should be ascribed to the consequent enhancement of urinary citrate rather than to an increase in urine $\mathrm{pH}$. Furthermore, because higher urine $\mathrm{pH}$ increases the risk of calcium phosphate, clinicians should carefully manage citrate supplementation, paying attention to its excessive enhancement in urine $\mathrm{pH}$.

\section{Materials and Methods}

\subsection{Chemicals}

Sodium phosphate dibasic, purity $\geq 99.5 \%$, was sourced from Merck (Darmstadt, Germany). Calcium nitrate tetrahydrate, purity $99 \%$, was sourced from Sigma Aldrich (Darmstadt, Germany). Potassium chloride, purity $\geq 99 \%$, and sodium citrate dibasic sesquihydrate, purity $\geq 99 \%$, were sourced from Carlo Erba Reagents (Cornaredo, Italy).

Standard $\mathrm{KOH} 0.1 \mathrm{~mol} \mathrm{~L}^{-1}$ and $\mathrm{HCl} 0.1 \mathrm{~mol} \mathrm{~L}^{-1}$ solutions were prepared by diluting Merck (Darmstadt, Germany) concentrate products. The $\mathrm{KOH}$ solution was standardized against potassium hydrogen phthalate (Fluka, Puriss; Darmstadt, Germany). All solutions were prepared using grade A glassware and ultrapure water (conductivity $<0.1 \mu \mathrm{S}$ ).

A calcium stock solution $\left(0.1 \mathrm{~mol} \mathrm{~L}^{-1}\right)$ was prepared by dissolving calcium nitrate tetrahydrate in ultrapure water and titrated by EDTA.

\subsection{Apparatuses}

Potentiometric measurements were performed using the Metrohm mod. 713 potentiometer (resolution of $\pm 0.1 \mathrm{mV}$ ) coupled with a Metrohm combined glass electrode (mod. 6.0259.100), with internal reference $\mathrm{Ag} / \mathrm{AgCl} / 3 \mathrm{M} \mathrm{KCl}$, and the Amel mod. 338 potentiometer (resolution of $\pm 0.1 \mathrm{mV}$ ) coupled with a Radiometer Analytical calcium selective electrode (mod. ISE25Ca) and a Metrohm reference electrode $\mathrm{Ag} / \mathrm{AgCl} / 3 \mathrm{M} \mathrm{KCl}$ (mod. 6.0733.100). A Metrohm 765 Dosimat burette (minimum volume deliverable of $\pm 0.001 \mathrm{~cm}^{3}$ ) was used to deliver the titrant solution. The potentiometric titrations were 
carried out in a stream of purified nitrogen gently bubbled in the titration cell to avoid $\mathrm{O}_{2}$ and $\mathrm{CO}_{2}$ contamination. The measurement cells are maintained at a constant temperature of $37 \pm 0.1^{\circ} \mathrm{C}$ by means of water circulation from a thermocryostat (mod. D1-G Haake).

\subsection{Calibration and Titration Procedures}

The glass electrode was calibrated, in terms of $\mathrm{pH}=-\log \left[\mathrm{H}^{+}\right]$, by titrating $\mathrm{HCl}$ $5 \mathrm{mmol} \mathrm{L}-1$ solution at the same ionic strength value as the solution under study, with standard $\mathrm{KOH}$, in order to determine the formal potential $E^{0}$ before each experiment. The electrode calibration data were analyzed by the ESAB2M program [24] to refine the electrode parameters. This program was used to refine the formal potential $E^{0}$, the Nernstian slope at $37^{\circ} \mathrm{C}$, and the analytical concentration of the reagents.

The ISE-Ca ${ }^{2+}$ was calibrated in $-\log \left[\mathrm{Ca}^{2+}\right]$ units (pCa), recording the emf (electromotive force, $\mathrm{mV}$ ) values obtained by adding known volumes of calcium stock solution $0.1 \mathrm{~mol} \mathrm{~L}^{-1}$. The $\mathrm{Ca}^{2+}$ concentration of the calibrating solutions ranged between $2 \times 10^{-4}$ and $5 \times 10^{-3} \mathrm{~mol} \mathrm{~L}^{-1}$. The recorded values of emf were used for the internal calibration and allowed to calculate the slope and the $E^{0}$ of the Nernst equation for the ISE-Ca ${ }^{2+}$ at $37^{\circ} \mathrm{C}$. The procedure was applied before the addition of the ligands, citrate and phosphate. Then, alkalimetric titrations were carried out. The concentrations of the calcium in solutions ranged between $2 \times 10^{-3}$ and $5 \times 10^{-3} \mathrm{~mol} \mathrm{~L}^{-1}$, and the $\mathrm{Ca}^{2+}$ to citrate ratio used was 1:1, while the phosphate was always in excess with respect to the cation, and the phosphate to $\mathrm{Ca}^{2+}$ ratios were maintained between 1.5 and 4 . The concentration ratios between the components of the solutions were chosen based on the concentrations of these ions in the urine samples. The ionic strength was adjusted to $0.1 \mathrm{~mol} \mathrm{~L}^{-1}$ with $\mathrm{KCl}$. The solutions were titrated with $\mathrm{KOH}$ standard solution $0.1 \mathrm{~mol} \mathrm{~L}^{-1}$, and both $\mathrm{pH}$ and $\mathrm{pCa}$ were monitored during the titration. The $\mathrm{pH}$ range considered was 5.0-7.5. The titrations were carried out until the precipitation of calcium phosphate salt occurred. Each titration was repeated at least twice.

\subsection{Data Treatment}

The $\mathrm{pH}$-metric titration data were analyzed using BSTAC software [25] to determine the formation constants. The software employs an iterative and convergent numerical method, which is based upon the linear combination of the mass balance equations, minimizes the error squares sum on emf values, and considers possible variations of ionic strength among and/or during titrations. The software allows for optimizing the concentration of the components of the solution under study, and possibly constraining them.

The $\mathrm{pCa}$ values obtained by the measurements with ISE- $\mathrm{Ca}^{2+}$ were not used to define the formation constants of the $\mathrm{Ca}^{2+}$ because the overall variation of potential recorded by the ISE- $\mathrm{Ca}^{2+}$ during the titration process was very low, $\sim 5 \mathrm{mV}$, and this technique was considered to have unsuitable sensitivity. However, the experimental $\mathrm{pCa}$ values were compared with those calculated by the application of the chemical model to verify the consistency between them.

The species considered in the chemical model used for the data elaboration are reported in Table 1. The formation constants of the species were derived from literature data when possible (see refs. reported in Table 1). Suitable calculation processes were applied on the original literature values, if necessary, to obtain the $\log K$ values at the working conditions of ionic strength $I=0.1 \mathrm{~mol} \mathrm{~L}^{-1}, \mathrm{KCl}$ and $t=37^{\circ} \mathrm{C}$. In Table 1 , both original and extrapolated values were reported. The effect due to ionic strength was considered by the application of an Extended Debye-Hückel (EDH) equation [17], whereas the effect of the temperature was evaluated by linear interpolation of the $\log K$ values from data collected at 20,30 and $40{ }^{\circ} \mathrm{C}$, respectively [18].

The weak interactions between the phosphate and citrate anions with the potassium cation were considered in the chemical model, therefore the protonation constants of the phosphoric and citric acids are those estimated with non-interacting cations [18]. The species distribution diagrams were drawn using HySS software [26]. 


\section{Conclusions}

This work was aimed at assessing experimentally whether the formation of the $\left[\mathrm{CaPO}_{4}\right]^{-}$and $\left[\mathrm{Ca}\left(\mathrm{PO}_{4}\right) \mathrm{cit}\right]^{4-}$ species could be relevant in the chemical model proposed to explain the chemistry of urine, and consequently, to evaluate their effects on the saturation levels in urines at higher $\mathrm{pH}$ values. The formation constants of the two species were defined, and the new chemical model was tested on five different natural urine samples. Indeed, the $\left[\mathrm{CaPO}_{4}\right]^{-}$species was found to be of some relevance. The model in which it was included yielded slightly lower saturation values for all the tested urines, especially those with a higher $\mathrm{pH}$. On the contrary, the $\left.[\mathrm{CacitPO}]_{4}\right]^{4-}$ species results to be poorly significant in both synthetic and natural samples. At a urine $\mathrm{pH}$ of 7.5 , the fraction of calcium included in this ternary complex remained negligible and was always below $5 \%$.

The overall results of the present study make us confident to conclude that the existence of the ternary complex can be rejected. Conversely, the $\left[\mathrm{CaPO}_{4}\right]^{-}$species may have some impact on saturation levels, especially at higher $\mathrm{pH}$, and should be taken into account for calculations. Therefore, this species will be included in the chemical model used by Lithorisk ${ }^{\circledR}$ software [8] to take into account its formation in the estimation of saturation values, and to better assess the overall risk of kidney stones.

Supplementary Materials: Table S1: $\mathrm{pH}$ and concentrations of the components of the urine samples, Table S2: formation constants of the species considered to model real urine samples, Figure S1: speciation plots for the urine A and C, Figure S2: speciation plots for the urine D and E. Paragraph: Saturation level calculation.

Author Contributions: Conceptualization, M.M. and P.G.D.; methodology, P.G.D.; formal analysis, P.G.D. and S.B.; investigation, P.G.D. and S.B.; resources, C.D.S. and D.M.; data curation, P.G.D., S.B., and D.M.; writing —original draft preparation, M.M., P.G.D., and S.B.; writing—review and editing, M.M., P.G.D., C.D.S., and S.B.; visualization, S.B.; supervision, M.M., P.G.D., and C.D.S. All authors have read and agreed to the published version of the manuscript.

Funding: This research received no external funding.

Institutional Review Board Statement: Not applicable.

Informed Consent Statement: Not applicable.

Data Availability Statement: Data is contained within the article or Supplementary Materials.

Acknowledgments: This work was supported by the University of Turin and by the Italian Ministry of Education, Universities and Research.

Conflicts of Interest: The authors declare no conflict of interest.

\section{References}

1. Pearle, M.S.; Calhoun, E.A.; Curhan, G.C. Urologic Diseases in America project: Urolithiasis. J. Urol. 2005, 173, 848-857. [CrossRef] [PubMed]

2. Williams, J.C., Jr.; Gambaro, G.; Rodgers, A.; Asplin, J.; Bonny, O.; Costa-Bauzá, A.; Ferraro, P.M.; Fogazzi, G.; Fuster, D.G.; Goldfarb, D.S.; et al. Urine and stone analysis for the investigation of the renal stone former: A consensus conference. Urolithiasis 2021, 49, 1-16. [CrossRef] [PubMed]

3. Robertson, W.G.; Peacock, M.; Marshall, R.W.; Marshall, D.H.; Nordin, B.E. Saturation-inhibition index as a measure of the risk of calcium oxalate stone formation in the urinary tract. N. Engl. J. Med. 1976, 294, 52-249. [CrossRef] [PubMed]

4. Pak, C.Y.; Hayashi, Y.; Finlayson, B.; Chu, S. Estimation of the state of saturation of brushite and calcium oxalate in urine: A comparison of three methods. J. Lab. Clin. Med. 1977, 89, 891-901. [PubMed]

5. Robertson, W.G.; Peacock, M.; Nordin, B.E. Activity products in stone-forming and non-stone-forming urine. Clin. Sci. 1968, 34, 579-594. [PubMed]

6. Werness, P.G.; Brown, C.M.; Smith, L.H.; Finlayson, B. EQUIL 2: A basic computer programme for the calculation of urinary saturation. J. Urol. 1985, 134, 1242-1244. [CrossRef]

7. May, P.M.; Murray, K. JESS, a joint expert speciation system-1. Talanta 1991, 38, 1409-1417. [CrossRef]

8. Marangella, M.; Petrarulo, M.; Vitale, C.; Daniele, P.; Sammartano, S. LITHORISK.COM: The novel version of a software for calculating and visualizing the risk of renal stone. Urolithiasis 2021, 49, 211-217. [CrossRef] 
9. Ferraro, P.M.; Ticinesi, A.; Meschi, T.; Rodgers, A.; Di Maio, F.; Fulignati, P.; Borghi, L.; Gambaro, G. Short-term changes in urinary relative supersaturation predict recurrence of kidney stones: A tool to guide preventive measures in Urolithiasis. J. Urol. 2018, 200, 1082-1087. [CrossRef] [PubMed]

10. Marangella, M.; Daniele, P.G.; Ronzani, M.; Sonego, S.; Linari, F. Urine saturation with calcium salts in normal subjects and idiopathic calcium stone-formers estimated by an improved computer model system. Urol. Res. 1985, 13, 189-193. [CrossRef]

11. Lentner, C. Geigy Scientific Tables, 8th ed.; CIBA-Geigy: Basel, Switzerland, 1983.

12. Rodgers, A.; Allie-Hamdulay, S.; Jackson, G. Therapeutic action of citrate in urolithiasis explained by chemical speciation: Increase in $\mathrm{pH}$ is the determinant factor. Nephrol. Dial. Transplant. 2006, 21, 361-369. [CrossRef] [PubMed]

13. Amico, P.; Daniele, P.G.; Rigano, C.; Sammartano, S. Stability of calcium- and magnesium-citrate complexes in aqueous solution. Ann. Chim. 1982, 72, 1-24.

14. Daniele, P.G.; Rigano, C.; Sammartano, S. Formation and stability of calcium- and magnesium-phosphate complexes in aqueous solution at $37^{\circ} \mathrm{C}$. A potentiometric investigation by glass and calcium ion-selective electrodes in the ionic strength range $0.03<\mathrm{I}$ $<0.5$. Ann. Chim. 1982, 72, 341-353.

15. Zhang, J.; Ebrahimpour, A.; Nancollas, G.H. Ion associatopn in calcium phosphate solutions at $37^{\circ} \mathrm{C}$. J. Solut. Chem. 1991, 20, 455-465. [CrossRef]

16. Sigel, H. Stability, structure, and reactivity of mixed ligand complexes in solution. In Proceedings of the Coordination ChemistryXX: Invited Lectures Presented at the 20th International Conference on Coordination Chemistry, Calcutta, India, 10-14 December 1979; pp. 27-45. [CrossRef]

17. Casale, A.; Daniele, P.G.; De Robertis, A.; Sammartano, S. Ionic strength dependence of formation constants. XI. An analysis of literature data on carboxylate ligand complexes. Ann. Chim. 1988, 78, 249-260.

18. Daniele, P.G.; De Robertis, A.; De Stefano, C.; Gianguzza, A.; Sammartano, S. Salt effect on the protonation of ortho-phosphate between 10 and $50{ }^{\circ} \mathrm{C}$ in aqueous solution. A complex formation model. J. Solut. Chem. 1991, 20, 495-515. [CrossRef]

19. Daniele, P.G.; Rigano, C.; Sammartano, S. The formation of proton and alkali-metal complexes with ligands of biological interest in aqueous solution. Potentiometric study of the $\mathrm{H}^{+}-\mathrm{K}^{+}$-citrate system at $37^{\circ} \mathrm{C}$ and $0.03<\mathrm{I}<1.0$. Ann. Chim. 1980, 72, 119-130.

20. Daniele, P.G.; De Robertis, A.; Sammartano, S. The effect of urea on the protonation of acetate, oxalate, malonate, citrate and sulfate in aqueous sodium, potassium, calcium chloride and tetraethylammonium iodide. Ann. Chim. 1992, 82, 503-516.

21. Crea, F.; De Stefano, C.; Milea, D.; Pettignano, A.; Sammartano, S. SALMO and S3M: A saliva model and a single saliva salt model mfor equilibrium studies. Bioinorg. Chem. Appl. 2015, 267985. [CrossRef]

22. Daniele, P.G.; De Stefano, C.; Marangella, M.; Rigano, C.; Sammartano, S. URSUS: A computer program for urine speciation. Clin. Biochem. 1989, 13, 507-510.

23. Daniele, P.G.; Sonego, S.; Ronzani, M.; Marangella, M. Ionic strength dependence of formation constants. Part 8. Solubility of calcium oxalate monohydrate and calcium hydrogenphosphate dihydrate in aqueous solution, at $37^{\circ} \mathrm{C}$ and different ionic strength. Ann. Chim. 1985, 75, 245-250.

24. De Stefano, C.; Princi, P.; Rigano, C.; Sammartano, S. Computer-Analysis of Equilibrium Data in Solution Esab2M-An Improved Version of the Esab Program. Ann. Chim. 1987, 77, 643-675.

25. De Stefano, C.; Mineo, P.; Rigano, C.; Sammartano, S. Ionic strength dependence of formation constants. XVII. The calculation of equilibrium concentrations and formation constants. Ann. Chim. 1993, 83, 243-277.

26. Alderighi, L.; Gans, P.; Ienco, A.; Peters, D.; Sabatini, A.; Vacca, A. Hyperquad simulation and speciation (HySS): A utility program for the investigation of equilibria involving soluble and partially soluble species. Coord. Chem. Rev. 1999, 184, 311-318. [CrossRef] 